\title{
An Extensive Analysis of Mining in Nigeria Using a GIS
}

\author{
Murtala Chindo (Corresponding author) \\ Geography Department, University of Leicester \\ University Road, Leicester, UK \\ Tel: 441-162-523-837 E-mail: murtalachindo@yahoo.com
}

Received: April 15, 2011 Accepted: May 6, 2011 doi:10.5539/jgg.v3n1p3

\begin{abstract}
The Nigerian mineral sector is undergoing radical structural reforms to allow for maximal exploitation, in view of its potential in diversifying the national economy. As part of the reforms, mineral titles and permits are granted by a new mining cadastre system. This article examines the spatial distribution of the licences granted so far using the geographic information system (GIS). A simple spatial and attribute query was used to select all types of licences based on their locations. The country appears to be virgin territory with exploration in brown and greenfields extensively dominating mining by activity. This paper contends, however, that widespread mineral exploration has certain policy implications that, when put in place at this stage of mining project development, are likely to mitigate the problems associated with the extractive economy.
\end{abstract}

Keywords: Nigeria, GIS, Mining-cadastre, Licence, Mining, Exploration, Quarry, Small-scale

\section{Introduction}

Mining industries have been viewed as key drivers of economic growth and the development process (Bradshaw, 2005), and as lead sectors that drive economic expansion which can lead to higher levels of social and economic well being (Bridge, 2008:391). These possibilities, however, remain the subject of policy and intellectual debate. Arguments of this nature are captured in a large body of theoretical and empirical studies on the inability of mineral resources to promote sustained economic growth and development in mineral economies (see examples from Auty, 1993, 2004; Sachs and Warner, 1999, 2001; Ross, 1999). However, many countries such as Australia, Canada, Russia, India, Saudi Arabia and Botswana have depended on their mineral wealth to finance their societies. Australia benefitted from mineral export, earning up to AUD 59.2 billion in 2006 alone (ICMM, et al., 2007). Nigeria, together with Botswana, Angola, South Africa and Liberia, falls into the category of mineral economies: each of these countries has an extractive economy that is matured and which relies on mineral revenue (Solomon, 2000).

In recent times, the rising demand for primary commodities from fast-growing and emerging countries, especially China, has added to the persistent high level of mineral demand in developed countries (UNCTAD, 2007). Similarly, high mineral prices and demand have stimulated an investment surge in mineral exploration and production in particularly the developing countries (Okeke, 2008; Mahtani, 2008; Twerefou, 2009). In order to take advantage of increases in the price of commodities, as well as the push in the equities market, resource-rich countries like Nigeria have seen a new economic opportunity and development prospect arising from the exploitation of their mineral resources. Since the new decade, Morgan (2001) observed that nations were either reviewing or reforming their policies to liberalise the mining sector that would encourage the inflow of foreign capital for investment. This situation has led to growing competition between nations to capture investments and, consequently, minerals policy, legal frameworks and institutions were reformed to encourage foreign and local investments in the extractive sector, and to optimise the contribution of mining to the national economy. For example, Madagascar, Ghana, Tanzania, Peru, Argentina and Chile have achieved remarkable success in this regard (Girones et al., 2009). Solid minerals in the Nigerian context include all minerals and metals, excluding oil and gas. These minerals, unlike oil, occur in all the different components of the Nigerian geology. Some of them are of commercial value, while others are small and unprofitable to exploit. Indeed, all the states of the federation have a share of the mineral inventory of the nation (Obaje, 2009).

The Nigerian economy is largely dependent on oil; non-oil minerals have relatively weak roles. However, the current global economic downturn, in particular oil price volatility in the international market, has compelled the 
Nigerian government to reduce the risk of over-dependence on oil by paying considerable attention to solid mineral development. Nigerian mining has tremendous potential for economic development (Gyang et al., 2010). Davenport (2010) reported that the expansion of mining has the potential to contribute 15 per cent to Nigeria's GDP by the year 2015 from the present one per cent. So far, various policies have been formulated to regenerate the moribund sector for economic diversification and increased revenue. One of the key components of the mining reform was establishing a modern cadastre system that grants mining permits and licences.

The study, therefore, relies on the licencing regime operational in the Nigerian mining sector. This is because "licencing is one of several themes within the overall administration of regulations that affect the mining sector" (World Bank, 2009). In fact, licencing is the first point of entry into the mining business, the main point of interaction between investors and government, and all activities within the sector (reconnaissance $\rightarrow$ exploration $\rightarrow$ mining $\rightarrow$ reclamation $\rightarrow$ closure) are documented by the mining cadastre. Since licences portray the current status of mineral resource production, the aim is to present a simplistic way of contributing to understanding the extent of mineral activities in Nigeria. This is achieved using a GIS to present the potential scale of mining activities in relation to modern and recent mining cadastral system of the country. By using mineral titles it could be overlaid to identify areas demarcated for mining, and can be expanded to examine how it affects the built and physical environment. The paper is structured as follows. Section 2 describes the Nigerian cadastral system and the types of mineral rights it contain. Section 3 presents data source, requirement and analysis, and the findings are discussed in Section 4. The conclusion of the paper is stated in Section 5.

\section{The Nigerian mining cadastre and mining activities by permits}

As noted in the introduction, the Nigerian geo-physical terrain favours resource extraction across the length and breadth of the country. The development of mining in the economy, however, is not only dependent on the availability of resources, but has much more to do with the ways in which these commodity systems are socially organised (Bridge, 2010). These socially organised systems include political, economic and cultural processes, such as an efficient legal and regulatory framework, security of tenure, investment risks, transparency and efficient administration, all of which create a favourable climate for investment. In order to capture revenue from extractive activities, the Nigerian Constitution in the first instance states that all mineral resources belong to the government. The Federal Government as the owner of these resources grants permits, licences and leases for reconnaissance, prospecting and extraction to interested persons/organisations (Mining Act, 2007; Petroleum Act, 1990). In the solid minerals sector, any individual or organisation wanting to explore for, extract or sell minerals, must lawfully obtain the relevant licence from the Mining Cadastre Office (MCO).

Under the old regime (prior to 2006), the MCO operated under the mines department, not as an autonomous body. The mines department at that time concurrently supervised mining activities, which was characterised by a multiplicity of functions; outdated mineral titles that rendered the entire cadastre system opaque; and the issuance of mining rights without recourse to the Mining Act. Thus, the Nigerian mining cadastre was symbolised by policy inconsistency, where the policy makers had undue regard for the law. For example, the discretionary powers bestowed on the minister and other mining officials by the 1999 Mining Act provided an avenue for the arbitrary revocation and allocation of mining titles over the years. This lack of transparency and accountability has created an unfavourable investment climate for Nigeria to harness fully its multi-billion-dollar-valued solid minerals sector. The sector became flooded with speculators that discouraged genuine local and foreign mining investors. The extent of these problems was confirmed by the outcome of the reform exercise that led to the case-by-case revalidation of all the known mining titles/rights.

The desire to open up the mining sector predicated the need for a mining cadastre system. This system has the responsibility to administer mineral titles and maintain a cadastre register on behalf of the federal government, such that it gains investors' confidence, and provides information on the state of mining activities to the investors and the public. The mining cadastre is the substance of the Minerals and Mining Act of 2007, which guarantees a secure mineral rights system, by recording the geographical location, ownership, type of mineral rights and validity period, compliance with environmental obligations and social agreements, and also payment of required fees. The current state of modernising the cadastre system from a mining register to a mining cadastre allows for the acquisition of a variety of licencing scales that range from a few metres in the case of quarry or small-scale mining, to hundreds of square kilometres for exploration and eventual mining (Ozah et al., 2010). Whatever the scale, the new system captures all the transactions that take place during the lifetime of the mine - from application through to granting, fees payable, tracking of annual reports, change in ownership, and finally, relinquishment or revocation of the title. 
As a first step in implementing the cadastre system for mining in Nigeria, a computerised mining cadastre system was introduced, and in the process, mineral titles were revalidated. This modern approach can be a success if executed in a transparent manner, and with strict compliance with and recourse to the Mining Act. The search for and exploitation of Nigerian mineral resources according to the Mining Act is through an exploration licence, mining lease, quarry licence or small-scale mining lease depending on the scale of operation, type of mineral mined and the geology of the deposit. These various licences - in addition to water and reconnaissance permits - are issued by the MCO under the provisions of the Mining Act. As noted earlier, the rate of Nigeria's solid mineral resources exploitation is low in relation to the extent of deposits found across the country. The vast majority of mineral resources are either under-explored or not exploited at all. There is, however, concentration of mining on a small-scale in mostly Brownfield areas, exploiting residual minerals. These areas are known to have economic minerals such as gold, iron ore, tin and columbite, tantalite and coal that have been mined in the past.

A total of 2793 permits and licences obtained from MCO in 2009 were available for this study, excluding water and reconnaissance permits. There are 1658 for exploration; quarrying licences came second with 1003; mining on a medium-or large-scale recorded 180 licences, and the least is SSM with 116. As indicated in Figure 1, more than half of the activity in the solid mineral sector is on exploration and is dispersed across the country. The extraction of economic minerals by full mining operation at both large- and small-scale is less than quarrying by about 20 per cent. Quarrying, which involves the extraction of construction materials (such as asbestos, granite, pipe clay, slate, sand, stone, laterite and gravel), is the major mining activity in the country followed by small-scale mining. Illegal and artisanal miners that formalise their activity with the MCO are registered and grouped as 'small-scale mining'. Although illegal mining is widespread and deeply rooted in the country, the government did not recognise it as a formal economic activity, and so it was not reflected in the enumeration of those participating in solid minerals extraction. Solid minerals are distributed throughout the federation; however, some parts of the country are notably more active in mineral extraction than others because of geological factors, legal restrictions, and the rate of demand from local industries. For example, the current Mining Act prohibits dual licencing or overlapping of both petroleum and solid mineral licences. In the Niger Delta (oil producing region), mining licences are, however, limited to small-scale mining and quarrying for construction and industrial materials for the construction works in the oil industries and related activities.

\section{Materials and methods}

To determine the extent of the mineral licencing 'boom' at the national level requires not just traditional information about the quantity and types of mineral activities, but also information about the geographical location where the activity occurs. For example, the geographical locations of the different mining rights can be documented at a range of spatial scales, from an exploration licence that may cover a wider area (often 100s to 1000 s of square kilometres), to a small-scale licence that may relate to less than a hectare of land. The Geographic Information System (GIS), in this instance, combines this variety of scales and creates relationships to determine the spatial pattern of mining activities. Ideally, any GIS process or task consists of: input, manipulation, management, query and analysis, and visualisation (ESRI, 2010). These tasks have been summarised into three major components: database construction, analysis and results. Figure 2 indicates the components and subset of functions employed in this study. The procedures for the execution of the functions employed ArcMap 9.3 commands and routines.

The Nigerian mining cadastre is an official register containing the ownership, the areal extent, the value of mineral rights and the validity of mining rights in a given geographical location, established as a basis for legal, administrative and fiscal purposes, in the management of mineral resources. A shapefile containing the geometry of titles based on a pre-defined grid system, a defined spatial limit and extents, and numbers as identifiers, are the data required for analysis. A set of files containing descriptive and administrative data regarding the licences with numbers used as identifiers was obtained. Before proceeding with the analysis, the data were prepared and pre-processed into a uniform and compatible format. This is consistent with Longley et al.'s (2005) suggestion that GIS data need transformation to make them compatible with the mode of analysis. Following Langley and colleagues' suggestion, all databases in the GIS are in common projection and on the same scale so that they can overlay accurately. The database was initially obtained with the geographic coordinates system, but was geo-referenced to WGS_UTM_Zone_31N.

An overlay analysis was used to combine the characteristics of the datasets into one. Specific locations or areas that have a certain set of attribute values - that is, the different licences and boundaries were identified by attribute and spatial query. This approach was used to find locations where the mining licences are located throughout the country. For example, the different types of mining licences were arranged into layers. These new 
features in the form of layers are stored in the output layer without modifying the original input file layer. The end result of the GIS processes shows in graphic form the distribution of mining activities in Nigeria. This presentation in the form of maps allows policy-makers and the civil society to make informed decisions about how resource activities are distributed across the 36 states of Nigeria. However, the GIS may not determine how the resources are being used beyond their location.

\section{Results and discussions}

The digital nature of the mining cadastre made it possible for the information about mineral titles to be acquired and used for analysis. Since the approval of licences and updating of the modern cadastre is a daily exercise, the analysis and presentation is, however, limited to the period during which the data were obtained, but will nonetheless provide an overview of activities in the sector. An extensive analysis of the distribution of the revalidated mineral titles and permits obtained in 2009 was undertaken in the sections that follow, starting with the exploration licence.

\subsection{Mineral exploration}

Mineral exploration is the second stage in the life cycle of a mine after reconnaissance, and the beginning of scientific and technical evaluation of the mineral that could be extracted on an economically viable basis (Hartmen and Mutmansky, 2002). Exploration determines as accurately as possible the size and value of the mineral deposit, by utilising techniques similar to, but more refined than, those used in prospecting. Exploration generally shifts from surface to subsurface locations, using a variety of measurements to obtain a more positive picture of the extent and grade of the ore body. Exploration for new minerals or existing reserves can be undertaken by the mining company itself or in partnership with an exploration company, otherwise called the 'Juniors', particularly in greenfield areas. An exploration licence in the Nigerian context allows a licencee to explore for any type of mineral over an area not exceeding 200 square kilometres (Mining Act, 2007) for the duration of three years (renewable). The Mining Act specifies that for a licence to be issued, the applicant should demonstrate a willingness and commitment to conduct exploration activities in an environmentally and socially responsible manner. In reality, however, exploration licence applicants rarely follow the rules, and the cadastre office, although committed, does not have the capacity to fully implement this provision of the Mining Act. Based on the researcher's observation, an exploration application is considered and granted based on the availability of a vacant piece of land determined by the use of a global positioning system (GPS), evidence of availability of funds, a certificate of incorporation, and consent letter, regardless of whether or not the area is appropriate for mining under the law.

Many more minerals are being explored, including limestone, coal, phosphate, gold, lead and zinc, tantalite, manganese, barite and uranium that together account for more than 80 per cent of all mineral activities. Thus, Nigerian mining activity is currently dominated by exploration work that, if successful, may eventually progress to extraction on a large or small scale. This reality signifies that even though there are certain limitations within the permitting process, participation in the mineral sector is renewed in favour of exploration to determine the nature, quantity and profitability of the sector in the prevailing minerals market conditions. Two main reasons for the intensity of mineral exploration can be deduced. First, the geological potential of the area was obtained from knowledge of earlier or historic mining activities, which include areas of abandoned mines or progressive exploration and mining sites, as well as non-mining related activities such as land excavation and studies of hazards. There is also a "bandwagon effect" - the exploration success of one company can lead to a flurry of other companies acquiring rights or an intensification of activities in the proximal areas. For example, exploration activities in Kogi were based on historic mining of coal, iron ore, precious metals and tantalite among others. Similarly, Enugu is being explored for coal, Jos for tin and gemstones, and Zamfara for gold, silver and copper. The current case is that mineral exploration is not entirely concentrated in past mining areas; greenfield areas are also being explored with greater intensity from the north-west to north-central regions and from the south-west to the eastern part of the country.

Second, geosciences information in digital format made available by the geological survey of Nigeria is playing a significant role in opening up greenfield exploration. Exploration companies have taken advantage of relying on the data gathered and disseminated by the government in place of gathering the information themselves. In the mining business, the availability of quality and reliable geologic data is a pre-condition for investment. As such, the government has provided the catalyst for greenfield exploration by providing basic information that gives some idea of geologic potential. The availability of data promoted exploration investments in oil sands, barites, feldspar, quartz, marble, limestone, lead and zinc, and has led to the identification of 34 minerals considered strategic for Nigeria's development. Nevertheless, the transformation of Nigeria's macro-economy, 
political stability, legal and regulatory frameworks, and fiscal policies are the determinant factors for private, and in particular foreign investment in mineral exploration. With a favourable investment climate, therefore, it is not out of context or over ambitious to conclude that with successful discovery in exploration, full and extensive mining can begin to manifest around 2015. There are a number of environmental and social impacts of greenfield exploration and mining (refer to McAllister et al., 2001; Kitula 2005; Estives, 2008) that at this early stage determines the success or failure of mineral project.

In the past decade the major international exploration companies hardly showed more than a passing interest in Nigeria; however, some investors from China, South Africa and Canada are part of the five per cent that are beginning to show renewed interest in Nigerian mining. The Nigerian government (through its mining companies) is a major player in mineral exploration. The government has specific interest in gold, iron ore, coal, tin, copper, barites, talc and bitumen; as such it holds about five per cent of exploration. The remaining 95 per cent is owned by private individuals and corporate entities, out of which foreign companies make up less than five per cent. Some of the minerals sought after by both local and foreign companies include cassiterite, barite, gold, feldspar/quartz, galena, pyrite, lead/zinc, tantalite, and coal, among others. Precious metals such as gold and silver, and gemstones including tourmaline, quartz, and barite dominate exploration by type of mineral.

The exploration stage is indeed the first point of contact between the proposed mine and communities: at this point cordial relations are expected to be established. How that relationship is built and managed can determine the success or obstruct the take-off of further stages of mine development. Experience has shown that engagement and accommodation of concerns from the local community at the earliest stage of exploration decreases the risks associated with opposition and social conflict (see Bastida, 2001; Muradian et al., 2003; Sinnott et al., 2010).

\subsection{Mining lease}

The Nigerian government is receiving economic benefits from Dangote Industries, an indigenous cement company exploiting limestone, clay and laterite in central Nigeria. In a bid to attract economic opportunities like this, a number of mining licences are issued by the MCO on a daily basis. The Nigerian mining licence transfers ownership of a mineral from the federal government to the mining licence holder. Actual mining, whether surface or underground, begins at this stage, and the choice of method (s) depends on the characteristics of the ore body, environmental restrictions, safety, economics and geotechnical challenges. A mining lease can be obtained in two ways: (1) by complete or part acquisition of an existing mining property and (2) from the very basic position of obtaining the appropriate licence from prospecting to exploration and mining lease. The first option is uncommon but began to emerge with the privatisation of government-owned mining properties like the Nigerian Mining Corporation (NMC).

Evidence of mining on the ground was minimal even with the numerous changes adopted for improving the sector. Mineral extraction - whether fully operational or inactive - accounts for six per cent of the sector, and the intensity differs from one region to the other as the geology and regulation permits (Figure 3). In terms of regional variations, the north-central region which comprises Benue, Plateau and Kogi states is dominated by mining in brownfield areas. Tin, columbite and iron ore extraction dominate mining activities, followed by limestone and granite. The NMC, though inactive, still has mineral holdings in Niger and Plateau states. In the Enugu and Ebonyi states in the south-east, mining of coal, iron ore, laterite, and limestone is still ongoing. In the south-west, there are important deposits of limestone at Sagamu, Ibese and Ewekoro and phosphate at Idogo and Oshoshun that are mined by cement companies. The Nigerian Mining Corporation and other government-owned mining companies have 12 per cent share of the 180 mining titles spread across the country.

\subsection{Quarrying lease}

Quarrying of granite, marble, sandstone and gravels are helping in meeting the demand for infrastructural expansion in Nigeria. Among these, granite is the most common, available and affordable building material. Quarrying as an extractive economy provides much of the raw materials used in building works and construction. As Nigeria is developing new structures and expanding existing infrastructure such as roads, hospitals and buildings, there is a shortage in the number of quarries supplying construction materials. Apart from being a construction material, quarrying contributes to government revenues through permitting, royalties, explosive permits and blasting certificates. Quarrying is a labour-intensive activity, and so creates employment opportunities for both the industry and related services. About 1800 quarries were recorded in 1996 (NBS, 2008). Coincidentally, the number went down with the introduction of an import embargo on Nigeria by the Commonwealth in 1996. The sanctions succeeded in deterring the importation of quarry machines and spare parts that led to the eventual collapse of the sector. Beginning from 2005, with the reform of the sector, rising crude oil prices and the exclusion 
of duties on mining machineries, the quarry industries once again began to recover, while new continue to be registered. Currently, 1003 registered quarry sites are spread across Nigeria (Figure 3). Granite, marble, sand, laterite, clay and gravel dominate quarry activities by licences. By virtue of scale, any one quarry occupies an area of not more than five square kilometres, and the operation can be either on a small or large scale. Quarry distribution follows geology, the pattern of infrastructural spending and the rate of growth of a particular region. Abuja, Nigeria's capital city has the highest concentration of quarries that supply earth-materials for building and construction work. Likewise, quarries are located in close proximity to the capital cities of the various states.

In the south-west region (Ondo, Oyo, Ogun, Lagos, Ekiti and Osun states), construction aggregates are extensively distributed, accounting for 40 per cent of quarrying. The concentration of quarries in Ogun and Oyo compared to other states is because of their proximity to Lagos state, where aggressive construction works are undertaken. This is coupled with the limited supply of granite rocks for aggregates in Lagos. The proportion of quarrying is 10 per cent relative to other mining in the south-east. North-eastern Nigeria has less than 10 per cent, while the least number of quarries are found in the north-western part of the country. The south-south region (Niger Delta) has solid minerals out of which sand, salt and clay are exploited. Sand is extracted by dredging the massive riverbeds which symbolise the marine nature of the region and are used for reclamation by the oil industry, for brick making, and as a raw material for the Ughelli glass industry located in Delta State. Kaolinite is quarried by the Akwa Ibom ceramic industry. The estimated 16 million housing deficit (Ezekiel, 2010; Isah, 2011) and infrastructural development will continue to drive the demand for granite, marble, sand, gravels and other construction materials. In the federal capital alone, the supply shortfall of about 1.2 million tonnes of granite chippings is an indication that a ready market for quarry products has been established. With an estimated market value of about US\$16 million in 2009, quarry boom is just beginning in Nigeria.

\subsection{Small-scale mining lease}

A number of the mineral deposits in the country are too small in size to be economical for large-scale mining; hence, small-scale extraction becomes an option. Similarly, not all minerals can be economically mined at small-scale, as some minerals require large injections of capital in order to be exploited, and in such cases small-scale miners can explore minerals and negotiate with mining companies for large-scale extraction. Because of the extensiveness of superficial mineral deposits in small quantities, government interest in small-scale mining has grown in the last couple of years, and as the industrial infrastructure needs of the country grow, small-scale miners supply raw materials that would otherwise be imported. Small-scale mining activities are concentrated in the long-standing mineral-rich veins of the younger granite and sedimentary basin of north-central and south-western Nigeria. Tin in the Plateau, lead/zinc in Kogi, barytes in Benue, and tantalum and alluvial gold deposits in Zamfara, Oyo and Osun States, are the dominant minerals and sites of SSM operations (Figure 3). Some minerals are mined superficially in shallow primitive underground mines; others are re-working the brownfield or tailings left by past mining. The reworking of deposits from historic mining is a common display of SSM.

The degree of participation varies by commodity and is, to an extent, determined by the availability of mineral deposits and access to markets; less so by quantity, ease of excavation, and the availability of water for processing. The increasing number of SSM leases suggests that the activity is becoming widespread in the country, although the concentration of activity varies with the effects of cyclical changes in global and local demand for commodity, macro-economic conditions and technological skills. The use of tantalite in mobile phones has spurred a flurry of SSMs searching for and extracting tantalite in Zamfara, Kaduna, Nassarawa, Kogi and Niger States. The small amount of materials needed for digging and uncomplicated processing flow makes this subsector attractive as a poverty alleviation strategy in a country where about two-thirds of the population falls below the poverty level.

Small-scale mining activities have not been well documented in the past - about 95 per cent of them operate illegally (Lawal, 2002). Tantalite, columbite, coal, gold, barite, tin, lead and zinc, tourmaline and barites are all extracted at small-scale. This study finds that in the last five years, the government has made efforts to organise artisanal and small-scale mining (ASM) from an individual or family holding into a formal sector through mining cooperatives. This effort has yielded results as about four per cent of mining activities in Nigeria comes from ASM. This, however, does not reflect the actual reality, because as this sector is still characterised by informal status, it is difficult to capture an accurate or even reliable number of ASM sites operating across the country. For instance, Nassarawa and Kaduna States are the nucleus of ASM; yet so far they have not one registered small-scale miner. Despite the difficulty in gathering data on the activities in this subsector, the number has been increasing exponentially in the past few months. The number of registered ASMs also increased from 116 recorded in May 2009 to 234 in October 2009. 
The Nigerian government obtained a soft loan from the World Bank, part of which has been used to increase the government's capacity to manage small-scale mining as a poverty reduction strategy. A closer scrutiny of this approach, however, indicates that the SSMs apparently have no capacity to initiate environmental protection measures (e.g. the EIA) or even address social problems (e.g. the CDA). In such instances, the environmental and social costs of SSM production are borne by the host communities rather than the SSM cooperatives and associations.

\section{Conclusion}

This paper has analysed the stages of mining activities in Nigeria according to the number of licences and permits issued by the MCO. Based on the aggressive reforms undertaken by the government to revitalise the solid minerals sector, the study found that a number of mining companies showed interest, as attested to by the mineral titles granted. A study of the mineral titles using the GIS method has identified their geographical spread. Out of these titles, exploration dominates mineral activity, followed by quarry, mining lease and small-scale mining respectively. The wider spread of exploration across all states of the federation indicates the beginning of intensive mining activities that will contribute to national income, diversification and employment in the near future. One of the limitations of the presentation is the inability to capture illegal mining activities that is predominantly practiced in the country. A temporal analysis would have been possible if data issued on year-on-year basis is available. This was not the case because the data used was total of the revalidated mineral titles of previous years. A modern mining cadastre system requires more than just the title holder or the date of grant of application. The database contained by a mining cadastre must be uniform and updated regularly. For this reason, the cadastre system must take a process-based approach, which takes into account the administrative and legal life-cycle of resources development as the foundation for their management.

The findings also suggest that additional analysis of mining can be gained by examining the relationship between the mining licences and the established communities and natural environment. From the analysis mineral licences granted are overlapping the land area administrated by the State. Some minerals are now licenced and exploited within the boundaries of local communities. The MCO is unable to provide mining applicants with information concerning existing rights, because the data are simply not available. For example, a buffer zone between mining licences and settlements can be established to identify host communities based on their proximity to an issued mineral title. Similarly, an overlay analysis can be overlapped with environmental resources data to be able to understand impacts on the natural environment. This analysis, however, can be seen as a catalyst for using simple GIS techniques in mineral development policies and solving complex issues, such as conflict and security of tenure in mineral administration.

\section{References}

Auty, R. M. (1993). Sustaining development in minerals economics: the resource curse thesis. London: Routledge.

Auty, R. M. (2004). The political economy of growth collapses in mineral economies. Minerals \& Energy-Raw Matls Rep, 19 (4), 3-15. doi:10.1080/14041040410002423, http://dx.doi.org/10.1080/14041040410002423

Bastida, E. (2001). A Review of the Concept of Security of Tenure: Issues and Challenges. [Online] Available at: http://www.dundee.ac.uk/cepmlp/journal/html/vol7/article7-17.html (February 20, 2008)

Bradshaw, M. J. (2005). Population, resources, development and the environment. In: Daniels, P. et al, eds. An Introduction to Human Geography: Issues for the 21st century. 2nd ed. (Section 2).

Bridge, G. (2008). Economic geography: natural resources. In: International Encyclopaedia of Human Geography. Eds. Kitchin and Thrift. Elsevier.

Davenport, J. (2010). Nigeria aiming to grow mining's GDP contribution to $15 \%$ by 2015 . Mining Weekly, March 15, 2010. [Online] Available at: http://www.miningweekly.com/article/nigeria-to-grow-mining-sector -to-15-of-gdp-by-2015-2010-03-05 (April 20, 2010).

ESRI (Earth Systems Research Institute). (2010). What is GIS? Overview. [Online] Available at: http://www.esri.com/what-is-gis/index.html (April 20, 2010).

Esteves, A. (2008). Mining and social development: refocusing community investment and using multi-criteria decision analysis. Res Policy, 33, 39-47.

Ezekiel, E. (2010). Nigeria needs N45 trillion to tackle housing deficit-FMBN. Nigerian Business Forum, 18 Nov. 
Girones, E. O., Pugachevsky, A. \& Walser, G. (2009). Mineral Rights Cadastre: Promoting Transparent Access to Mineral Resources. Extractive Industries for Development Series \#4 June 2009. Washington DC: The World Bank.

Gyang, J. D., Nanle, N., Chollom, S. G. (2010). An overview of mineral resources development in Nigeria: problems and prospects. Continental J. Sustainable Development, 1, 23-31.

Hartmen, H., Mutmansky, J. (2002). Introduction to mining engineering. (2nd ed.) United States: John Willey.

ICMM, the World Bank and UNCTAD Commodities Branch. (2007). Synthesis of four country case studies: the challenge of mineral wealth using resource endowments to foster sustainable development. London: ICMM.

Isah, R. (2011). Nigeria: Making housing fund contribution national agenda. [Online] Available at: http://allafrica.com/stories/201106240782.html (June 30, 2011).

Kitula, A. (2006). The environmental and socio-economic impacts of mining on local livelihoods in Tanzania. $J$ Cleaner Production, 14, 405-414. doi:10.1016/j.jclepro.2004.01.012, http://dx.doi.org/10.1016/j.jclepro.2004.01.012

Lawal, M. (2002). Constraints to small-scale mining in Nigeria: policies and strategies for development. Centre for Energy Petroleum Minerals Law and Policy Annual Review - the Dundee Yearbook of International Natural Resources and Energy Law and Policy.

Longley, P. A., Goodchild, M. F., Maguire, D. J. \& Rhind, D. W. (2005). Geographic information systems and science. (2nd ed.). West Sussex, UK: John Willey and Sons Ltd, (Chapter 2).

Mahtani, D. (2008). The new scramble for Africa's resources. Financial Times Special Report, 28 Jan. 1-6.

McAllister, M., Scoble, M. \& Veiga, M. (2001). Mining with communities. Nat. Res. Forum, 25, 191-202. doi:10.1111/j.1477-8947.2001.tb00761.x , http://dx.doi.org/10.1111/j.1477-8947.2001.tb00761.x

Morgan, P. G. (2002). Mineral title management - the key to attracting foreign mining investment in developing countries? Trans. Instn Min. Metall. (Sect. B: Appl. earth sci.), B165-B170.

Muradian, R., Martinez-Alier, J. \& Correa, H. (2003). International capital versus local population: the environmental conflict of the Tambogrande mining project, Peru. Society and Natural Resources, 16 (9), 775-792. doi:10.1080/08941920309166, http://dx.doi.org/10.1080/08941920309166

NBS (National Bureau of Statistics). (2008). Facts and figures 2007. Abuja: NBS Headquarters.

Nigerian Minerals and Mining Act. (2007). Abuja: Ministry of Mines and Steel Development.

Obaje, N. (2009). Geology and mineral resources of Nigeria. London: Springer (Chapter 1). doi:10.1007/978-3-540-92685-6, http://dx.doi.org/10.1007/978-3-540-92685-6

Okeke, C. N. (2008). The second scramble for Africa's oil and mineral resources: blessing or curse? The International Lawyer, 42 (1), 193-210.

Ozah, A. P., Wever, T., Ghys, L. and Weissmann, T. (2010). Prospects, challenges and strategies in the implementation of the Nigerian computerised mining information system. In: International Society for Photogrammetry and Remote sensing (ISPRS): Core spatial databases-maintenance and services-from theory to practice. Archive Vol. XXXVIII, part 4-8-2-W9. Haifa, Israel, 2010.

Petroleum Act. (1990). Vesting of petroleum in the State, etc. Federal Republic of Nigeria.

Ross, M. (1999). The political economy of the resource curse. World Politics, 51 (2), 297-322. doi:10.1017/S0043887100008200, http://dx.doi.org/10.1017/S0043887100008200

Sachs, J. D. and Warner, A. M. (1999). The big push, natural resource booms and growth. J. Devt. Econs., 59, 43-76. doi:10.1016/S0304-3878(99)00005-X, http://dx.doi.org/10.1016/S0304-3878(99)00005-X

Sachs, J. D. and Warner, A. M. (2001). Natural resources and economic development: the curse of natural resources. European Econ.c Rev., 45, 827-838.

Sinnott, E., Nash, J. \& Torre, A. (2010). Natural Resources in Latin America and the Caribbean: Beyond Booms and Busts? Washington DC: The International Bank for Reconstruction and Development/The World Bank. doi:10.1596/978-0-8213-8482-4, http://dx.doi.org/10.1596/978-0-8213-8482-4

Solomon, M. H. (2000). Growth and diversification in mineral economies: planning and incentives for diversification. South Africa: United Nations Centre for Trade and Development. 
Twerefou, D. K. (2009). Mineral Exploitation, Environmental Sustainability and Sustainable Development in EAC, SADC and ECOWAS Regions. African Trade and Policy Centre Work in Progress, 79. Economic Commission for Africa.

UNCTAD (United Nations Conference on Trade and Development), (2007). World investment report 2007: transnational corporations, extractive industries and development. New York and Geneva: United Nations.

World Bank Group. (2009). Sector licensing studies: Mining sector. [Online] Available at: http://www.ifc.org/ifcext/fias.nsf/AttachmentsByTitle/BRG_Toolsimproveexistingreg_OtherMining/\$FILE/Sect orLicensingStudiesMining.pdf (April 2, 2011)

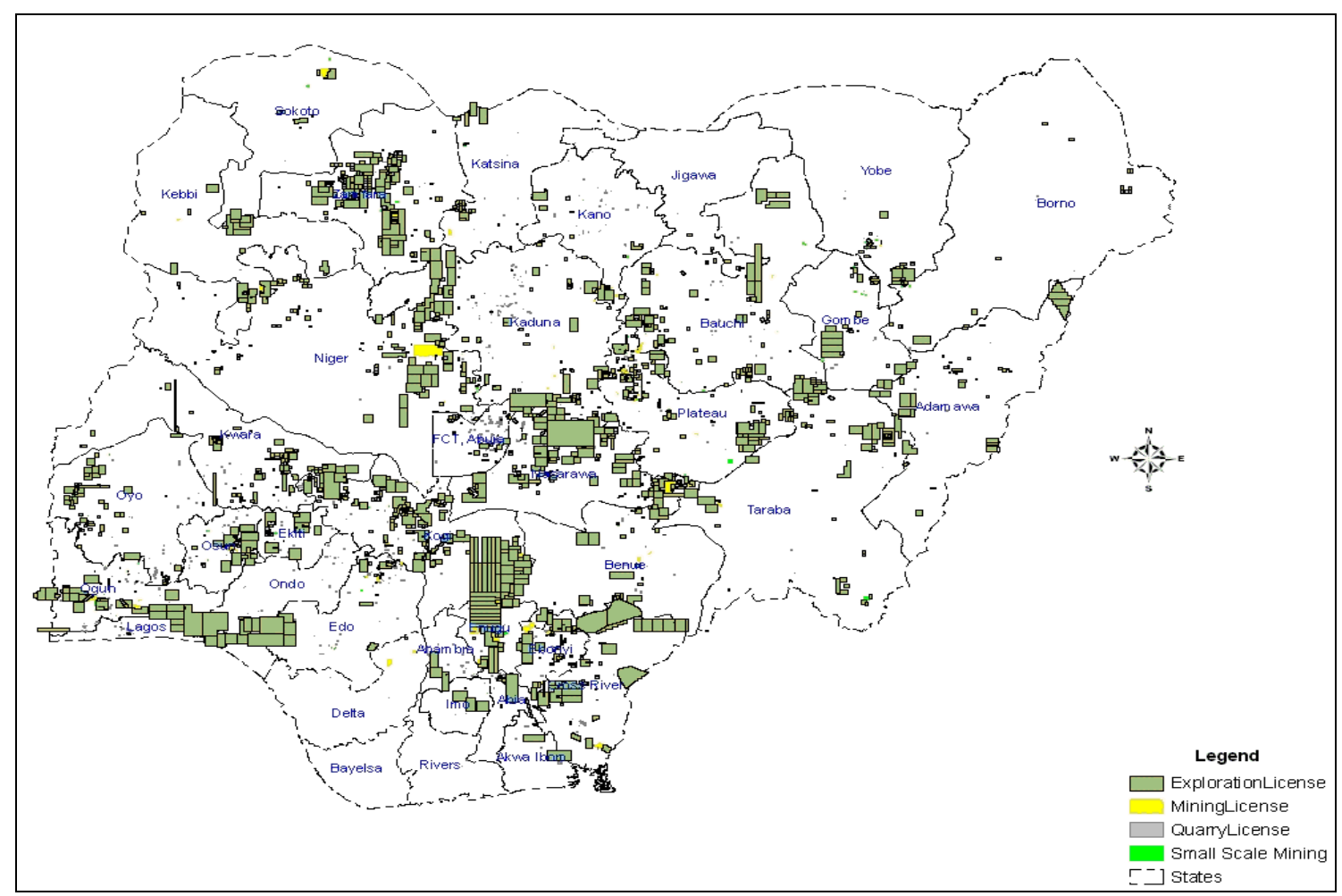

Figure 1. Mineral activities by permits in Nigeria.The map shows the spread of licences/permits granted for mineral extraction at various stages of development. Exploration licences have formed a cluster in the north-central, north-west and the south-east 


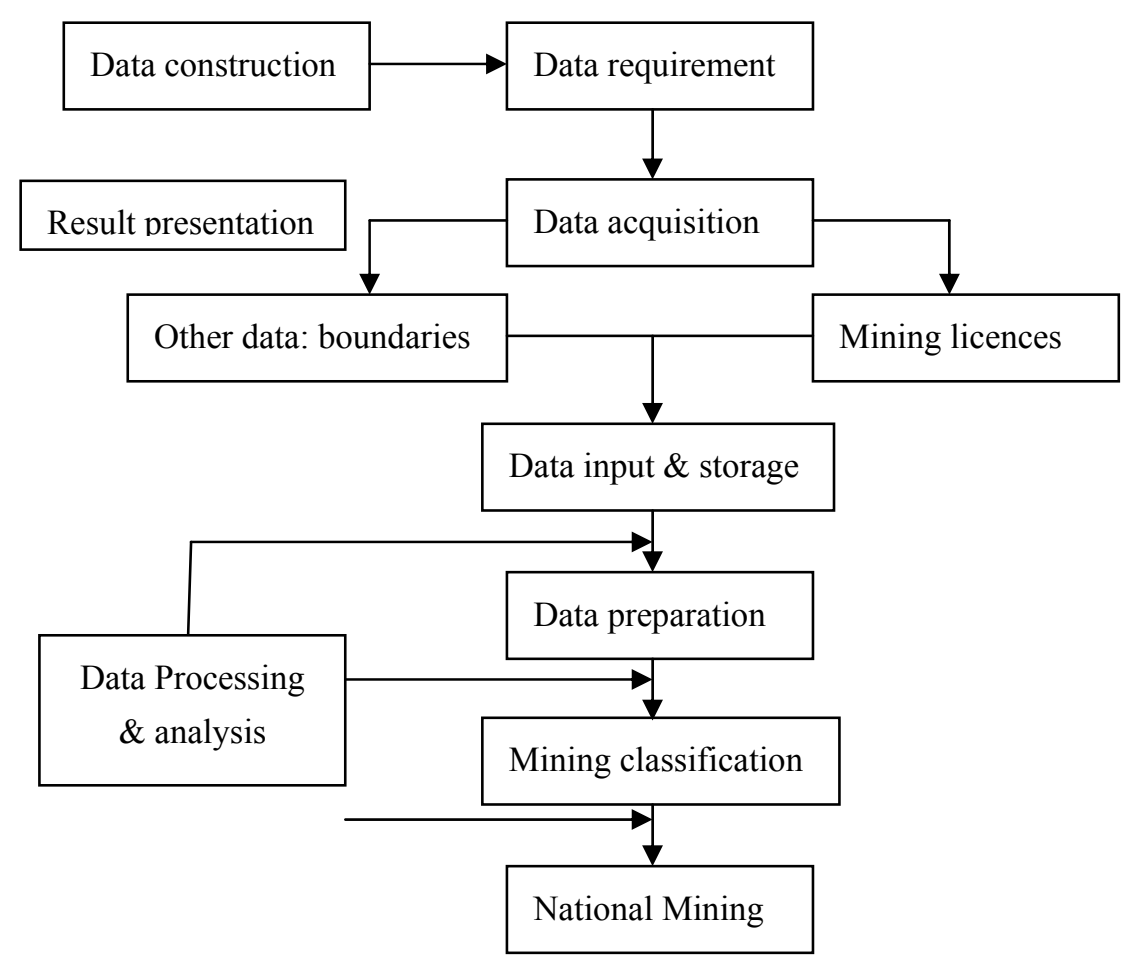

Figure 2. The GIS processes. It shows the three major tasks and steps taken to create the national overview of mining
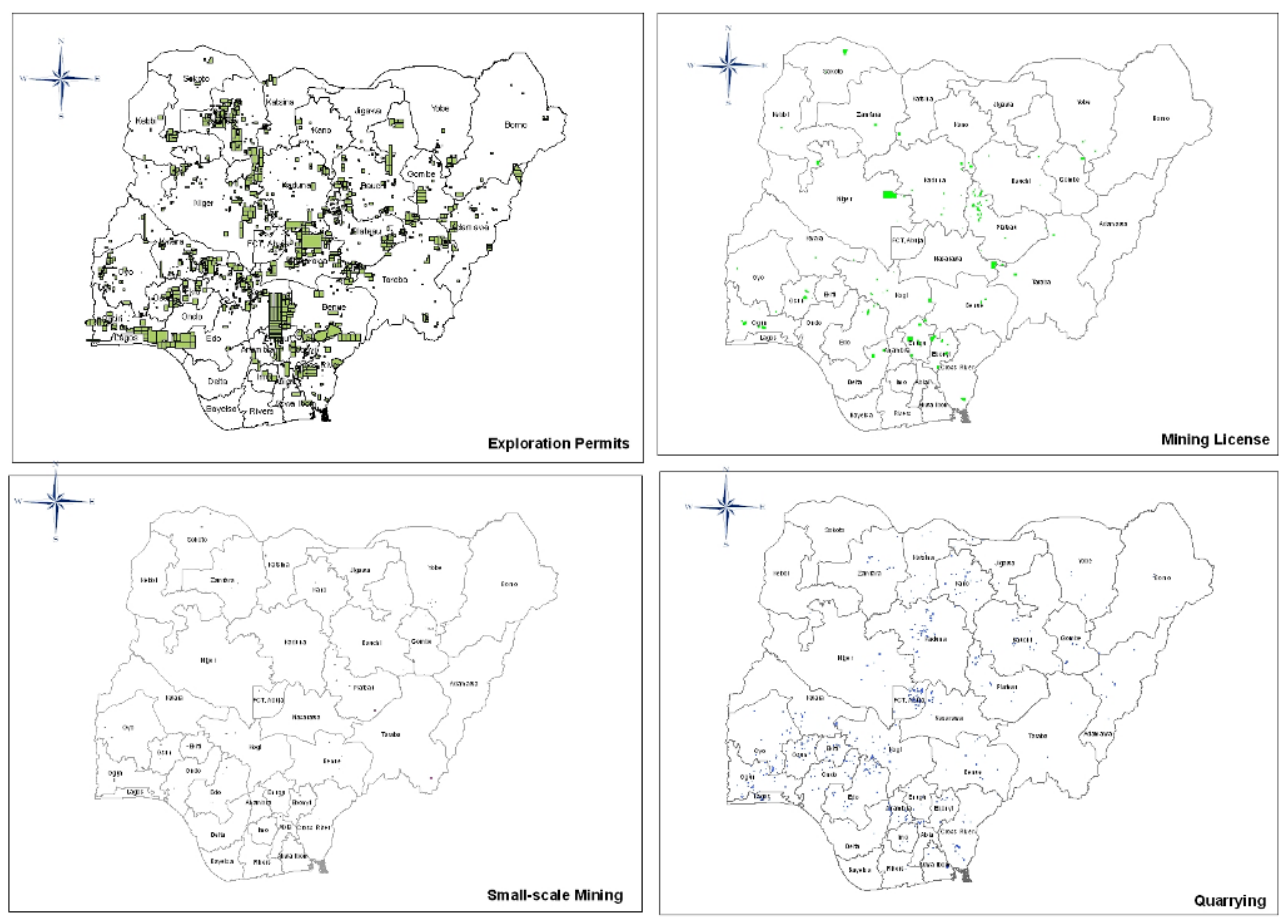

Figure 3. Exploration, mining, small-scale and quarry licences and permits.

The proportion is $6 \%$ mining; $4 \%$ small-scale; $34 \%$ quarrying and $56 \%$ exploration respectively 